\title{
Governance Structures: A Complementary Study of Transaction Costs, Measurement Costs And Strategic Resources
}

Cleiciele Albuquerque Augusto ${ }^{1}$ - Universidade Estadual de Maringá - Departamento de Administração José Paulo de Souza² - Universidade Estadual de Maringá - Departamento de Administração

ABSTRACT The objective of this study is to understand how governance structures are formed, considering transaction costs, measurement costs and strategic resources. To that end, bibliographic research was carried out in order to explore the complementarity of three theories: Transaction Cost Theory (TCT), Measurement Cost Theory (MCT) and Resource-Based View (RBV). A combined approach indicates that having strategic resources (RBV) may characterize a property right that needs to be protected by governance structures that consider transaction attributes and behavioral assumptions (TCT) and the measurability of resources involved (MCT) in transactions.

Keywords: Assets. Measurable dimensions. Vertical integration. Property rights. 


\section{INTRODUÇC̃̃O}

The main thread behind this work regards the transactional and strategic characteristics that influence make or buy decisions in organizations. In other words, understanding the guidance and outlook in the decisions to internalize or outsource production, establishing relationships with other companies. Understanding the motivating aspects responsible for these decisions shows the way to comprehending organizations, in their traits, boundaries, and relationship and production dynamics.

At the core of these decisions is the choice of governance structures, understood as the forms used by agents to organize their transactions. These structures are defined between the choice for arrangements that prioritize in-house production of activities or products, which is done by vertical integration, or by acquiring them externally, which can occur through agreements with third parties or on the free market, as specified by Williamson $(1975,1985,1996)$.

With regard to the choice of governance structures, some theories were developed in an attempt to serve as guidance in decision-making and enable greater organizational efficiency. Traditionally, some New Institutional Economics (NIE) approaches have been used, particularly Transaction Cost Theory (COASE, 1937; WILLIAMSON, 1975, 1985, 1996; KLEIN; CRAWFORD; ALCHIAN, 1978; ZYLBERSZTAJN, 1995, 2009) and Measurement Cost Theory (COASE, 1937; BARZEL, 2003, 2005; ZYLBERSZTAJN, 2009). In this context, the minimization of Transaction costs and measurement of agent coordination emerge as the main aspects in determining the appropriate governance structure.

More recently, some scholars have looked at Resource-Based View (RBV) for theoretical foundations on the configuration of governance structures (LANGLOIS, 1992; LANGLOIS; FOSS, 1997; POPPO; ZENGER, 1997; COMBS; KETCHEN, 1999; JACOBIDES; WINTER, 2005; ARGYRES, ZENGER, 2008, 2012; SAES, 2009). In general, these authors evidence the importance of the condition of the strategic resourcel in the decisions whether to internalize or outsource production, reinforcing the strategic focus inherent to theories. In this work, we use the term "strategic resources" as synonymous with distinctive resources and capabilities, generating competitive advantages, as referenced in Peteraf (1993) and Wernefelt (1984). 
When considering the proposed approaches, it should be emphasized that, in TCT, transaction costs are reduced as an alignment occurs between governance structures, transaction attributes (asset specificity, frequency and uncertainty) and the existing behavioral assumptions (bounded rationality and opportunism) (WILLIAMSON, 1985). According to this approach, if external transaction costs are greater than internal governance costs, the company tends to integrate vertically. A decisive element in this decision towards internalization is the specificity of transacted assets, which can take place either in location, physical and human terms, or in terms of dedicated, temporal and brand assets (WILLIAMSON, 1996).

MCT, proposed by Barzel (2005), implies in accepting that transaction attributes alone could not explain the choice of governance structure, requiring other dimensions involving the guarantee of property rights, the condition of measurement and information on transacted assets. Other aspects that can be identified as influencing the definition of governance structure, from the theoretical-analytical scope of MCT, refer to standardization (BARZEL, 2003, 2005). Under these conditions, the company would seek vertical integration if the measurement costs of the assets involved in the exchange were high.

RBV indicates that the resources and differentiated capabilities a firm possesses are responsible for creating and sustaining its competitive advantages (PENROSE, 1959, WERNEFELT, 1984; BARNEY, 1991; PETERAF, 1993). According to these authors, distinguishing resources exist due to the assumption of the heterogeneity of firms - that is, the approach considers that companies are different sets of resources that complement one another and generate different competitive capabilities. These competitive capabilities are achieved only because they are built over the path dependence of the company (TEECE; PISANO; SHUEN, 1997) - that is, on the particulars of its historic trajectory. They generate competitive advantages by creating ricardian rents - higher income due to possession of these resources that are scarce in the market (BARNEY, 2007). Under this perspective, the company would integrate vertically (besides it's not treated directly in this approach), aiming to protect and control the strategic resources over which it has capacity or aiming to create income by sustaining a superior capability over its competitors. 
According to these assumptions, in addition to the basic aspects of these approaches, three central constructs can be identified that determine the choice of governance structures based on the theoretical approaches presented herein: transaction costs (TCT), measurement costs (MCT) and strategic resources (RBV).

If theses constructs were taken individually in the definition of the governance structure, they have criticism. Although TCT and TCM occupy the same space as part of the strand of efficiency, Barzel (2005) supports that the idea of measurement costs of assets is more operational than the notion of asset specificity, proposed by Williamson (1985). In a similar way, Williamson (1985) affirms the feasibility of using the measurement in the evaluation of performance in supplying products and services, although ratifying the importance and interdependence of these theories. RBV, in turn, although it considers the generation of value through strategic resources and capabilities, it is criticized for its restraint in not dealing with property rights issues on the generated value (FOSS, 2005). The ramifications of these issues leads to the definition of the following guiding question: How the complementary treatment of TCT, MCT and RBV minimize the limitations observed when these approaches are viewed individually?

This work proposed a perspective of complementarity between all three approaches, in an attempt to better explain the specificities present in the transactions and undertake a more complete analysis of the determinants of the boundaries of the firm. Similar attempts have been observed in the literature for the Theory of the Firm. One of them refers to the integration of RBV and TCT (LANGLOIS, 1992; WILLIAMSON, 1999; COMBS; KETCHEN, 1999; MAHONEY, 2001; LEIBLEIN, 2003; FOSS, 2005; JACOBIDES; WINTER, 2005; ARGYRES; ZENGER, 2008, 2012; SAES, 2009, AUGUSTO; 2011, CROOK et al., 2013). In addition, RBV has also been linked to Strategic Position Analysis SPA (MONTGOMERY; PORTER, 1998; NICKERSON, 2003; SAES, 2009) and Knight's Theory of Profit - KTP (NICKERSON; ZENGER, 2004; SAES, 2009). TCT, for its part, has also been discussed for its links to MCT (ZYLBERZSTAJN, 2005, 2009). Nevertheless, no studies have been observed that aim to discuss a complementary perspective of TCT with MCT and RBV. 
Therefore, in the present investigation, transaction costs (TCT), measurement costs $(\mathrm{MCT})$ and strategic resources $(\mathrm{RBV})$ are considered together to explain the formation of governance structures in the strategic context of organizations. As such, this work aims to understand how governance structures are formed by considering transaction costs, measurement costs and strategic resources.

To meet that objective, the study presents this first section to introduce the proposed theme. The second section indicates the methodological path employed, identifying the guiding categories and subcategories of the suggested proposition of complementarity. The presentation of the theoretical reference used on TCT, MCT and RBV, focusing on building propositions of their complementary aspects, is done in the third section. The fourth section contains the final considerations acquired from the analysis of the collected materials. Lastly, references are provided.

\section{METHODOLOGY}

This is a bibliographic research study, of a qualitative nature and descriptive type. The general assumption of the present investigation indicates that governance structures are configured by combined consideration of transaction costs, measurement costs and strategic resources involved in intra- and inter-firm coordination. As such, transaction costs, measurement costs, strategic resources and governance structures represent the categories of the present study, with an existing set of subcategories for each category, to aid the analysis and guidance in discussing the complementarity of the proposed approaches. This reasoning can be observed in Figure 1. 
Figure 1 - Categories and subcategories under study.

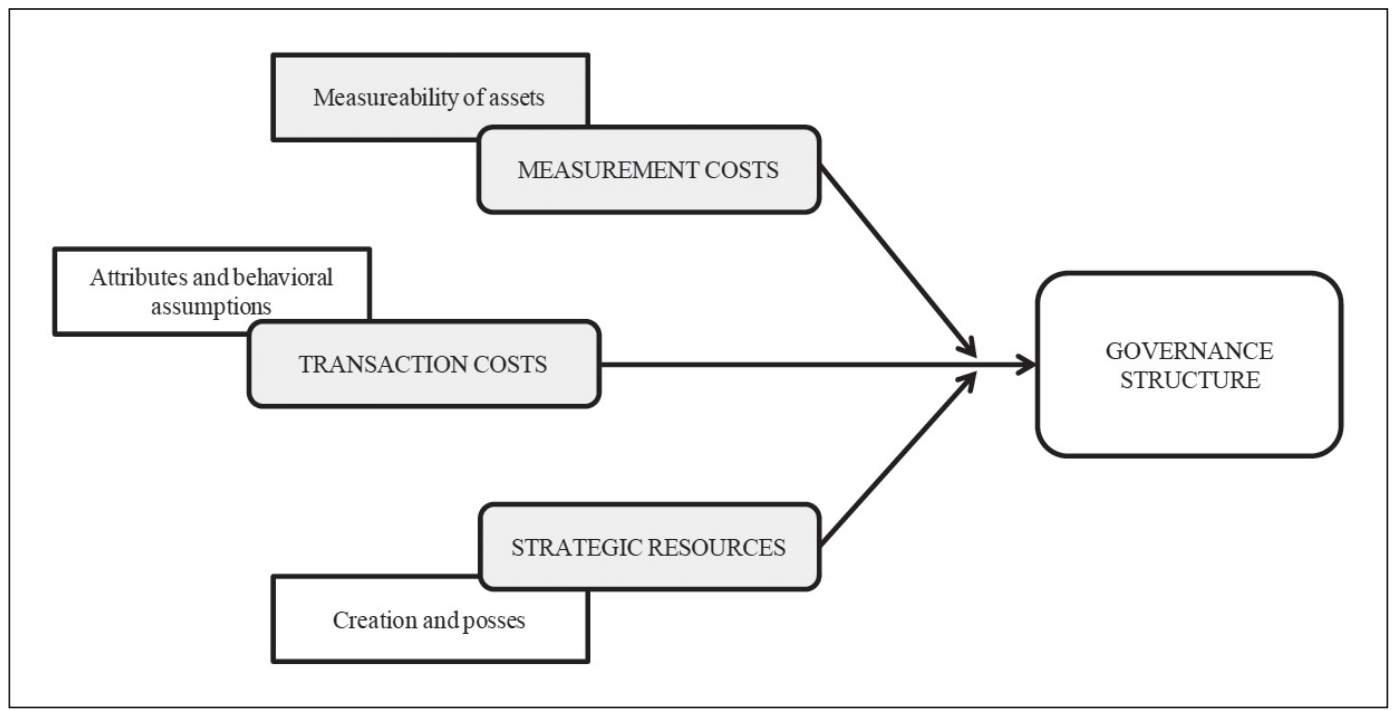

Source: Formulated by the authors.

\section{THEORETICAL PROPOSITIONS OF COMPLEMENTARITY BETWEEN TCT, MCT AND RBV}

In this topic, some propositions are made regarding the complementarity of the three discussed approaches: RBV, TCT and MCT, combined. It is considered that, individually, TCT and MCT are related, respectively, to the possibility of reducing transaction costs and guaranteeing property right in measurable dimensions. RBV, for its part, focuses on identifying and exploring strategic resources and capabilities for the organization, capable of sustaining a competitive advantage against its market competitors.

A complementary perspective is sought between TCT, MCT and RBV. As such, we can see that, TCT and MCT have their origin justified in the importance of institutions. Defining institutions as the constraints that structure interactions, providing incentives and defining the historical performance of 
economy, North (1991, p. 98) put it: "Institutions and the effectiveness of enforcement (together with the technology employed) determine the cost of transacting". RBV, in turn, starts from the assumption that strategic resources can emerge from competition in imperfect markets, which generate opportunities for their identification (PETERAF, 1993). In that case, we highlight that a first proposition regarding the complementarity between all three theoretical contributions is found in the following argument: institutions, of central importance to TCT and MCT, establish the rules of the game and guarantee property rights over strategic resources in imperfect markets (RBV), assuring competitive benefits from ex ante and ex post barriers.

A necessary step to treat complementarity of these approaches is to define the unit of analysis. In this respect, while TCT and MCT focus, as a unit of analysis, on the transaction, there still is no consensus on the unit of analysis of RBV - to Barney (1991) it is the strategy; to Peteraf (1993), the resources. Considering the unit of analysis proposed by Peteraf (1993), another proposition regarding the complementarity of the approaches is found in the argument that strategic resources transactions (RBV) are characterized by attributes, behavioral assumptions (TCT) and measurable dimensions (MCT). In other words, in addition to presenting a certain measurable dimension (MCT), each strategic resource of the firm (RBV) can also be characterized in terms of specificity, frequency and uncertainties, and be subject to a certain level of bounded rationality and possibility of opportunistic behavior (transaction attributes and behavioral assumptions through TCT).

The main process indicates, therefore, that while TCT states that transaction characteristics determine the choice of governance structures (WILLIAMSON, 1985), through MCT, this choice is made taking in consideration the difficulties resulting from the measurement of transacted products (BARZEL, 2003). Through RBV, choice will be influenced by the presence or not of strategic resources (BARNEY, 1991, 2007; PETERAF, 1993). With that, another proposition of complementarity emerges from the realization that the characteristics of the transaction, measurement and strategic resources define the proper governance structures, not only to generate efficiency but for strategic performance. 
In this context, governance structure via vertical integration, specifically, can be adjusted in the presence of strategic resources, with high specificity and difficulties in measuring their dimensions. In that sense, this form of governance acts as a protection mechanism against opportunistic behaviors and wealth appropriation, indicating contributions to sustain competitive advantages due to generated controls. When considered by TCT's perspective, control is related mostly to the minimization of uncertainty, considering that specialized investments were made (WILLIAMSON, 1985, 1996). "Thus, as firms move transactions from markets to hybrids to hierarchies, increased authority allows for greater monitoring and control and simplifies dispute resolution" (CROOK et al., 2013, p. 65).

In complement, control in MCT works as a mechanism to guarantee that the measurable dimensions present in the transaction are maintained. Strategic resources $(\mathrm{RBV})$, on the other side, need to be controlled in order to maintain their condition of non-mobility. As a complementary perspective, control, even if directed towards reducing resource mobility, allows responses under conditions of uncertainty and guarantee of property rights over measurable assets to be more effective.

As a result, the inductive proposition formed indicates that the presence of specific, hard-to-measure and strategic resources influences the choice for governance structures that tend towards vertical integration. This reasoning can be observed in Figure 2.

Figure 2 - Determinant factors of vertical integration.

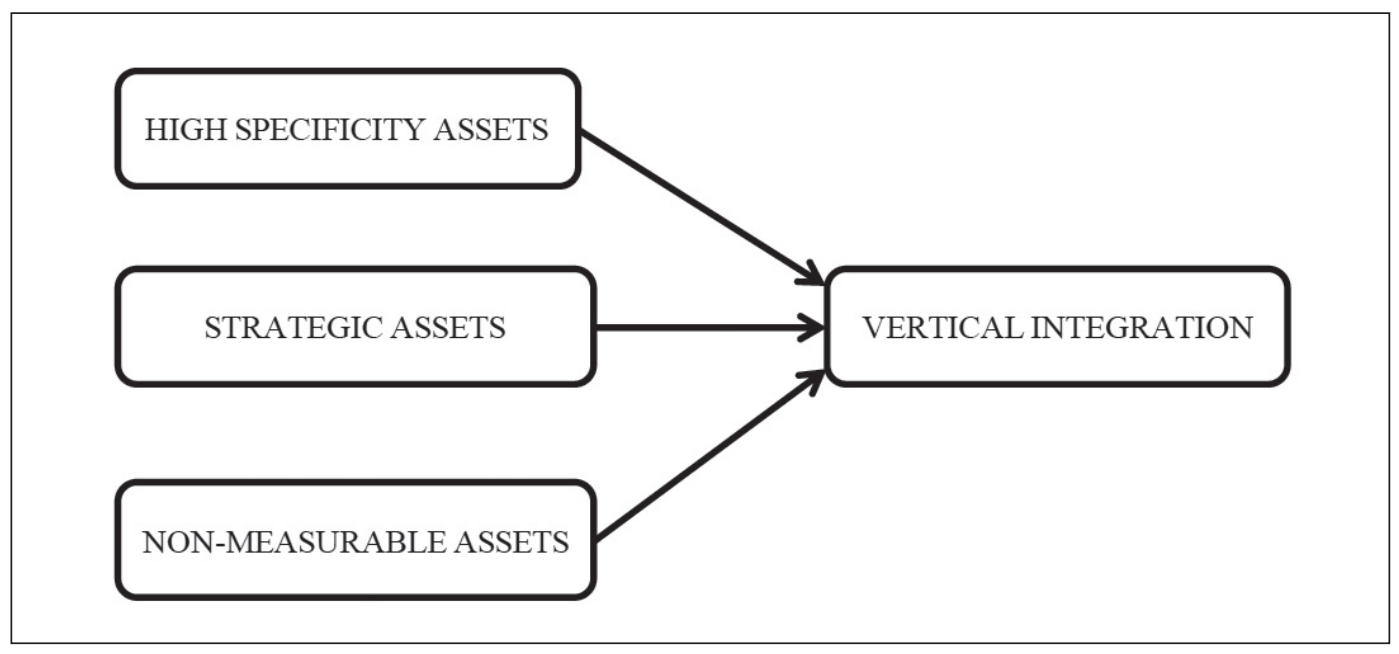

Source: Formulated by the authors. 
In this context, it is worth highlighting the consideration of Crook et al. (2013) on strategic resources and specific assets. The authors assure that "[...] strategic assets are a subset of specific assets; a strategic asset is, by definition, specific [...] (CROOK et al., 2013, p. 68). The converse, however, is not necessarily true: although specific assets create value because they are specialized for a transaction and therefore more productive than general assets, they are not always rare. Thus, the specific assets, as described in TCT, are intrinsically valuable, which is one of the three criteria that define strategic assets (BARNEY, 1991), but there are many specific assets that are not necessarily rare or difficult to imitate or substitute (CROOK et al., 2013).

By taking a closer look at governance structures, another view can be had on the decision to vertical disintegration of production. As Langlois contends (1992, p.109): "no company - even the most integrated ones - has the necessary capabilities for all activities in the chain of production". Therefore, the result is that companies must negotiate with other companies that can offer them the necessary capabilities, which usually occurs through market contracts or in the free market. In this perspective, the boundaries of the firm are determined by the relative force of the internal and external capabilities to the company.

As such, the logic for integration and disintegration in RBV is that, in general, "vertical disintegration would prove superior to vertical integration whenever complementaries do not exist within the company or are inferior to those available in the market" (LANGLOIS, 1992, p. 119). From TCT, we can affirm that external resources are available to the firm through contracts, and the firm can opt to use them if the governance costs to generate them internally were high (COASE, 1937). In MCT, according to Barzel (2003), the company would disintegrate its activities when there is no difficulty measuring the goods involved in the exchange or in defining the transacted property rights.

To Melo (2006), firms interact because there is a limit to the internalization of productive activities in terms of efficiency. As internalization is one of the means for firm growth, the factors that limit this growth can be understood as motivations that lead to the establishment of supply relationships in detriment to self-production. The supply relationships come to be required, according to Melo (2006), for three reasons: 1) an increase in internal production costs; 2) an increase in internal coordination costs, due to deficiencies in the internal organization of production; 3) a need for technical competencies, due to technical specialization of the firms. 
As such, we suggest that: firms opt to vertical disintegration their production not only due to an increase in production costs, coordination costs or ease of measurement, but also because of the need for competences or assets are not available internally or are inferior to those existing in the market.

Still dealing with externalization, another valid aspect of complementarity, related to the formation and selection of governance structures, regards the possibility of contracting, considering the treatment of strategic resources in the scope of TCT and MCT.

Given all three approaches, when considering the outsourcing of productive activities, the presence of a strategic resource creates an opportunity to devise a strategy (RBV), but can also creates problems with opportunism and loss of property right. This is because the specific properties of the transacted resource can establish conditions for opportunistic behaviors to occur (TCT), as already highlighted by Foss (2005). Moreover, the asymmetry of information in the measurement process (MCT) can impact the distribution of wealth and property rights involved in the transaction (BARZEL, 2005).

The possibilities of losses associated with opportunistic behavior and information asymmetries generate costs to the organization and can undermine competitive strategies directed at creating and sustaining advantages. Thus, in addition to the production costs involved, coordination costs (transaction costs and measurement costs) can emerge. Therefore, governance structures come to be used to guarantee the continuity of the transaction at the lowest cost.

Considering the choice of governance structure by TCT, the presence of high-specificity strategic resources makes impossible the occurrence of the transaction in the market or through contractual relationships (WILLIAMSON, 1991). Hierarchical control, or vertical integration, therefore emerges as the adequate alternative for competitive advantage to be sustained and to eliminate the possibility of opportunistic behavior. On the other hand, when considering MCT, the possibility of measurement of product attributes favors the use of contracts to regulate the transaction (BARZEL, 2005), as it enables and offers the guarantee of the rights involved and the required specificities. As such, the combined consideration of both theories indicates that the contractual relationship, involving measurement, features the same potential of vertical integration to sustain competitive advantages. 
With that, we are given the following proposition: If possible to measure product attributes, the contractual relationship can be used to guarantee property rights over strategic resources and high-specificity assets, thus avoiding the costs of vertical integration. In other words, measurement consideration provides an alternative to vertical integration, by considering the form of the contract as sufficient structure to govern a transaction, even if highly specific. On the other hand, whenever the use of contracts is not capable of guaranteeing property rights and avoiding the possibility of value dissipation, reducing the sustainability of the competitive advantage, vertical integration can be chosen.

Chart 1 is presented, hypothetically, for a better understanding of the possible variations in governance structure that can emerge in organizational relationships, given the characteristics of transacted resources (specific, measurable and strategic). Note that in total absence of high-specificity resources, measurable and strategic, the market emerges as the best option. At the other extreme, the presence of these resources indicates integration or contracting as an adequate option to enable a reduction in transaction costs (TCT and MCT) and the sustainability of competitive advantage (RBV).

It should be observed that measurement makes contracting feasible in the presence of strategic high-specificity resources due to the possibility of measuring the goods involved in the transaction. If the possibility of measurement were not considered in high-specificity situations, the available options of governance structures would be limited to vertical integration. According to this same Figure, it is noted that the sustainability of competitive advantage would take place through the alignment between specific, measurable and strategic resources that require governance structures that tend towards vertical integration. 
Chart 1 - Governance structures possibilities given resource characteristics.

\begin{tabular}{|c|c|c|c|c|c|c|c|c|}
\hline Resource Type & \multicolumn{7}{|c|}{ Condition } \\
\hline Specific & - & - & - & - & + & + & + & + \\
\hline Measurable & - & - & + & + & + & + & - & - \\
\hline Strategic & - & + & + & - & + & - & - & + \\
\hline Governance structure & $\mathrm{M}$ & $\mathrm{VI}$ & $\mathrm{VIIC}$ & $\mathrm{M}$ & $\mathrm{VI} / \mathrm{C}$ & $\mathrm{VI} / \mathrm{C}$ & $\mathrm{VI}$ & $\mathrm{Vl}$ \\
\hline Competitiveness & Neutral & $\mathrm{CCV}$ & $\mathrm{CCV}$ & Neutral & $\mathrm{SCV}$ & $\mathrm{CCV}$ & $\mathrm{CCV}$ & $\mathrm{CCV}$ \\
\hline
\end{tabular}

Note 1 - M: market/ C: contract / VI: vertical integration. Neutral: random competitive advantage/ CCV: creation of competitive advantage/ SCV: favorable condition for the sustainability of competitive advantage.

Note 2 - "-" means absent and "+" means presence.

Source: Formulated by the authors.

Underlying these assumptions, others emerge as well, notably in the consideration of analytical interactions. Considering that specific assets, in TCT, consist of those assets that cannot be reemployed without loss in its productive value (WILLIAMSON, 1985), new aspects can be added by adding the RBV and MCT approaches.

From the proposal by Combs and Ketchen (1999) that, as with specific assets, strategic resources are characterized by the difficulty in commercialization and imitation, the identification of which resource is strategic can be inferred by identifying specific assets. Given its condition of value creation and differentiated competitive condition, strategic resources come to require adequate coordination mechanisms. As Williamson pointed (1996, p. 237) "Organization also has a bearing on the distribution of rents as well as asset protection". Moreover, when considering assets and resources under the prism of MCT, the creation of information, control and measurement that guarantee the property rights of those involved prove essential.

In this perspective, the following proposition is offered: a) strategic resources tend to be specific assets, because they necessarily imply creating value for a given purpose; b) specific assets represent strategic resources whenever their presence, in addition to value loss against a second transaction alternative, indicates differentiated competitive conditions against the competition; c) the maintenance of the competitive conditions of specific assets and strategic resources depends on generating information and control that can guarantee the property rights involved. 
Lastly, the rational indicates that the support for competitive advantage requires governance structures capable of protecting strategic resources that take transaction and measurement characteristics into account. As such, the generic proposition, regarding the closure of the ideas contained in Chart 1, indicates that possession of strategic resources (RBV) can characterize a property right that needs to be protected by governance structures that take into account transaction attributes and behavioral assumptions (TCT) and the measurability of the assets involved (MCT).

This proposition can be reinforced by the statements of Argyres and Zenger (2008). According to those authors, one could think that RBV consists of how to deal with the issue of which resources complement one another to produce a competitive advantage, whereas the Theory of the Firm deals with the issues of which of these complementary resources will stay under common property of the company and which will be owned independently. Following this line of thinking, Combs and Ketchen (1999) affirm that, while RBV emphasizes the identification of strategic resources that require improvements, the Theory of the Firm focuses on the way to manage these resources after they were identified - that is, on the most adequate governance structures to coordinate them and guarantee the maintenance of competitive advantages.

Foss and Foss (2004) argue that one of the failures of RBV is that, according to that approach, differences in competitive advantages are a question of how efficient are the resources that the companies control, and not how well the resources are organized or managed. This means there is little or no attention paid to the task of management or to organizational issues in RBV. Following this argument, Foss (2005) adds that one of the gaps of this approach is in the interaction between value creation and value appropriation. According to the author:

[...] this interaction is extremely important to understand the economic implications of reward systems and property rights attribution. A large share of modern economic theory of the firm focuses around this, the problem of Hold-up, and is an important manifestation of the sharing of the expected leftover impacting the creation of this leftover (through the effect on specific investments) (FOSS, 2005, p.75). 
To Foss (2005), this insight is still surprisingly lacking in RBV. In that sense, complementarity is valid, given that identifying the strategic resources of the firm is not enough to create and capture value. The consideration of TCT and MCT is in the sense of contributing to mitigate this criticism, by indicating how structures will tend to be configured, in order to assure property rights and stop value capture in transactions. Chart 2 is proposed considering comparative aspects between TCT and MCT, proposed by Zylbersztajn (2005, p. 26) and the results discussed above.

Chart 2 - Proposition of complementarity regarding TCT, MCT and RBV.

\begin{tabular}{|c|c|c|c|c|}
\hline Aspect & $\mathrm{TCT}$ & MCT & RBV & $\begin{array}{l}\text { Propositions regarding } \\
\text { TCT, MCT and RBV } \\
\text { complementarity }\end{array}$ \\
\hline Origin & $\begin{array}{l}\text { Importance of } \\
\text { institutions. }\end{array}$ & $\begin{array}{l}\text { Importance of } \\
\text { institutions. }\end{array}$ & $\begin{array}{l}\text { Competition in } \\
\text { imperfect markets } \\
\text { (PENROSE, 1959). }\end{array}$ & $\begin{array}{l}\text { Institutions establish the } \\
\text { rules of the game and } \\
\text { guarantee property right } \\
\text { over strategic resources in } \\
\text { imperfect markets assuring } \\
\text { competitive benefits from ex } \\
\text { ante and ex post barriers }\end{array}$ \\
\hline Unit of analysis & $\begin{array}{l}\text { Transaction: } \\
\text { resulting from the } \\
\text { characteristics } \\
\text { of frequency, } \\
\text { asset specificity } \\
\text { and uncertainty } \\
\text { (attributes), as } \\
\text { well as behavioral } \\
\text { assumptions linked } \\
\text { to opportunistic } \\
\text { behavior and } \\
\text { bounded rationality. }\end{array}$ & $\begin{array}{l}\text { Transaction: } \\
\text { broken down } \\
\text { into measurable } \\
\text { dimensions. } \\
\text { A set of economic } \\
\text { and legal rights } \\
\text { are exchanged and } \\
\text { guaranteed by the } \\
\text { State or privately. }\end{array}$ & $\begin{array}{l}\text { Strategy (BARNEY, } \\
\text { 1991). } \\
\text { Resources (PETERAF, } \\
\text { 1993). }\end{array}$ & $\begin{array}{l}\text { Transactions that involve } \\
\text { strategic resources are } \\
\text { characterized by attributes, } \\
\text { behavioral assumptions } \\
\text { (TCT) and measurable } \\
\text { dimensions. }\end{array}$ \\
\hline Main Process & $\begin{array}{l}\text { Transaction } \\
\text { characteristics } \\
\text { influence the choice } \\
\text { of governance } \\
\text { structure. }\end{array}$ & $\begin{array}{l}\text { Measurement } \\
\text { characteristics } \\
\text { influence the choice } \\
\text { of governance } \\
\text { structure. }\end{array}$ & $\begin{array}{l}\text { Resources } \\
\text { characteristics } \\
\text { influence the choice } \\
\text { of governance } \\
\text { structure. }\end{array}$ & $\begin{array}{l}\text { The characteristics of the } \\
\text { transaction, measurement } \\
\text { and strategic resources } \\
\text { define governance } \\
\text { structures. }\end{array}$ \\
\hline
\end{tabular}




\begin{tabular}{|c|c|c|c|c|}
\hline Aspect & TCT & MCT & RBV & $\begin{array}{l}\text { Propositions regarding } \\
\text { TCT, MCT and RBV } \\
\text { complementarity }\end{array}$ \\
\hline $\begin{array}{c}\text { Vertical } \\
\text { Integration }\end{array}$ & $\begin{array}{l}\text { Higher level of asset } \\
\text { specificity implies } \\
\text { greater vertical } \\
\text { integration or long- } \\
\text { term agreements. }\end{array}$ & $\begin{array}{l}\text { Difficulty in } \\
\text { measuring attributes } \\
\text { implies greater } \\
\text { vertical integration. } \\
\text { Property rights are } \\
\text { placed with whoever } \\
\text { offer guarantees. }\end{array}$ & $\begin{array}{l}\text { Control over } \\
\text { strategic resources } \\
\text { demands a vertical } \\
\text { integration. }\end{array}$ & $\begin{array}{l}\text { The presence of specific, } \\
\text { hard-to-measure and } \\
\text { strategic resources defines } \\
\text { governance structures } \\
\text { that tend towards vertical } \\
\text { integration. }\end{array}$ \\
\hline $\begin{array}{c}\text { Vertical } \\
\text { Disintegration }\end{array}$ & $\begin{array}{l}\text { Whenever } \\
\text { governance costs to } \\
\text { generate activities } \\
\text { internally are higher } \\
\text { than acquiring them } \\
\text { externally. }\end{array}$ & $\begin{array}{l}\text { Whenever there is no } \\
\text { difficulty measuring } \\
\text { the goods involved } \\
\text { in the exchange or in } \\
\text { defining transacted } \\
\text { property rights. }\end{array}$ & $\begin{array}{l}\text { Whenever } \\
\text { complementary } \\
\text { resources are not } \\
\text { available internally } \\
\text { or are inferior to } \\
\text { those available in } \\
\text { the market. }\end{array}$ & $\begin{array}{l}\text { Firms opt to contract their } \\
\text { production not only due to } \\
\text { an increase in production } \\
\text { costs, coordination costs or } \\
\text { ease of measurement, but } \\
\text { also because of the need for } \\
\text { competences or assets are } \\
\text { not available internally or are } \\
\text { inferior to those existing in } \\
\text { the market. }\end{array}$ \\
\hline Contracts & $\begin{array}{l}\text { The presence of } \\
\text { high-specificity } \\
\text { assets prevents } \\
\text { market transaction } \\
\text { or through } \\
\text { contractual } \\
\text { relationships, } \\
\text { requiring integration. }\end{array}$ & $\begin{array}{l}\text { The possibility of } \\
\text { measuring the } \\
\text { attributes of the } \\
\text { product makes } \\
\text { it feasible to use } \\
\text { contracts to regulate } \\
\text { the transaction. }\end{array}$ & $\begin{array}{l}\text { Strategic resources } \\
\text { can cause problems } \\
\text { with opportunism } \\
\text { and loss of } \\
\text { property rights and } \\
\text { wealth, requiring } \\
\text { a governance } \\
\text { structure capable } \\
\text { of diminishing the } \\
\text { transaction costs } \\
\text { generated. }\end{array}$ & $\begin{array}{l}\text { If possible to measure } \\
\text { product attributes, the } \\
\text { contractual relationship } \\
\text { can be used to guarantee } \\
\text { property rights over } \\
\text { strategic resources and } \\
\text { high-specificity assets, thus } \\
\text { avoiding the costs of vertical } \\
\text { integration. }\end{array}$ \\
\hline
\end{tabular}




\begin{tabular}{|c|c|c|c|c|}
\hline Aspect & $\mathrm{TCT}$ & MCT & RBV & $\begin{array}{l}\text { Propositions regarding } \\
\text { TCT, MCT and RBV } \\
\text { complementarity }\end{array}$ \\
\hline $\begin{array}{l}\text { Analytical } \\
\text { interactions }\end{array}$ & $\begin{array}{l}\text { Specific assets } \\
\text { cannot be } \\
\text { reemployed without } \\
\text { a loss in productive } \\
\text { value }\end{array}$ & $\begin{array}{l}\text { In order to preserve } \\
\text { their condition as } \\
\text { specific assets and } \\
\text { strategic resources, } \\
\text { information } \\
\text { creation, control and } \\
\text { measurement are } \\
\text { essential. }\end{array}$ & $\begin{array}{l}\text { As specific assets, } \\
\text { strategic resources } \\
\text { are characterized } \\
\text { by a difficulty in } \\
\text { commercialization } \\
\text { and imitation. }\end{array}$ & $\begin{array}{l}\text { a) strategic resources } \\
\text { tend to be specific assets, } \\
\text { because they necessarily } \\
\text { result in value creation for } \\
\text { a given purpose; b) specific } \\
\text { assets become strategic } \\
\text { resources whenever their } \\
\text { presence, in addition to } \\
\text { loss in value for a second } \\
\text { transaction alternative, } \\
\text { indicates differentiated } \\
\text { competitive conditions } \\
\text { against the competition; c) } \\
\text { the maintenance of these } \\
\text { competitive conditions } \\
\text { depends on creating } \\
\text { information and control } \\
\text { that guarantee the property } \\
\text { rights involved. }\end{array}$ \\
\hline Rational & $\begin{array}{l}\text { Governance } \\
\text { structure results } \\
\text { from the perspective } \\
\text { of alignment } \\
\text { with transaction } \\
\text { attributes and } \\
\text { behavioral } \\
\text { assumptions. } \\
\text { Minimization of } \\
\text { transaction costs. } \\
\text { Decision is made } \\
\text { ex-ante, considering } \\
\text { ex-post risks. }\end{array}$ & $\begin{array}{l}\text { Results of internal } \\
\text { organizational } \\
\text { structure from } \\
\text { the perspective of } \\
\text { maximizing value. } \\
\text { Decision is made at } \\
\text { any time }\end{array}$ & $\begin{array}{l}\text { Strategic resources } \\
\text { must be maintained } \\
\text { and controlled. } \\
\text { Property right } \\
\text { guarantees are } \\
\text { necessary to explore } \\
\text { opportunities. } \\
\text { Decision is made } \\
\text { ex ante to generate } \\
\text { superior ex-post } \\
\text { resources and } \\
\text { capabilities. }\end{array}$ & $\begin{array}{l}\text { The creation and possession } \\
\text { of strategic resources can } \\
\text { characterize property right } \\
\text { that needs to be protected } \\
\text { by governance structures } \\
\text { that take into account } \\
\text { transaction attributes and } \\
\text { behavioral assumptions } \\
\text { (TCT) and the measurability } \\
\text { of the assets involved (MCT). }\end{array}$ \\
\hline
\end{tabular}

Source: Formulated by the authors. 
An additional aspect could be considered in this proposal, the learning process. In that regard, we can propose suggest that in the treatment of governance structures and strategic resources, the learning process stands out as a fundamental aspect. Langlois (1992, p. 105) affirms that "[...] there cannot be a full theory on the limits of the firm without considering in detail the learning process in companies and markets". Thus, to that author it is essential to consider that a given theory of firm growth must take into account that, in the long term, the agents involved undergo a learning process, which makes it so they have more information about one another.

Likewise, Saes (2009) further highlights the issue of learning as determinant in the choice of governance structures. The author affirms that TCT explains which governance structures are more efficient to explore the strategic resources of the firm. RBV, for its part, supports the choice of governance structures, especially given that changes in these structures depend on a feedback process from the leaning and personal experiences of managers on the transaction costs involved.

When considering the learning process, Langlois (1992) defends the existence of dynamic governance costs, which refer to costs of information or knowledge related to the transfer of capabilities from companies to the market, or vice-versa. According to the author, these costs exist due to the fact that, over time, the competences of organizations undergo changes resulting from learning and technological and organizational innovations.

Williamson (1999), in his work "Strategy research: governance and competence perspectives", admits that the history of the firm, its resources and learning - aspects discussed in RBV - influence the choice of the proper governance structure, and consequently the boundaries of the firm. In the author's perception, the Theory of the Firm became too limited by focusing on issues such as property rights and the role of asset specificity, acknowledging that the roles of organizational knowledge and learning are treated superficially.

In that regard, it is noteworthy that the role of learning shows importance in all three theoretical approaches considered. In TCT, learning can support the choice of governance structure, reduce bounded rationality, ex ante uncertainties and make agreements less incomplete. In MCT, it can optimize information, generate better conditions for control, standardization, measurement and 
formalization of property rights. In RBV it can act in generating resources and sustaining ex post competitive advantages, as well as in management ability, establishing conditions for ex ante and ex-post barriers to be feasible. As such, as in the case of transaction and measurement characteristics, resources and capabilities related to the learning process justify the choice of governance structure.

From the suggested assumptions, we observe the possibility of treating the formation and boundaries of governance structures by collectively considering all three proposed theoretical frameworks. In that sense, strategic resources transactions (RBV) are characterized by attributes, behavioral assumptions (TCT) and measurable dimensions (MCT) that must be considered. Thus, coordination under the focus of TCT and MCT emerges as a mechanism not only to reduce transaction costs, but also to obtain and sustain superior competitive conditions through the governance of strategic resources.

\section{CONCLUSIONS}

The attempt to integrate the different strategy approaches is a recent movement, but which has seen several initiatives. In this study, this movement is presented in the search for a more thorough understanding of the boundaries of the firm, in order to minimize individual limitations in terms of strategic analysis by considering NIE, notably TCT and MCT, and RBV. Note that the criticisms against these approaches when considered individually motivate these movements and indicate the need to add new analytical elements. These criticisms can be seen in Theory of the Firm literature, especially when dealing with TCT and MCT, as well as in the RBV approach.

Following the aim to understand how governance structures are formed by considering transaction costs, measurement costs and strategic resources, some paths was developed. On the one hand, we note that part of the criticisms leveled at the Theory of the Firm refer to the unilateral approach present in the choice of boundaries of the firm. In other words, the definition of governance structures involves more than the presence of transaction costs, specific assets, opportunistic behaviors and measurement costs. On the other hand, internal resources and organizations' capabilities, which create sustainable competitive advantages, can influence how the boundaries of the firm are configured and must be coordinated. In that sense, the RBV approach can prove valid in responding to some limitations highlighted in TCT and MCT, and vice-versa. 
The idea is to open pathways to explore the relationships between these theoretical approaches, as the progresses obtained in this field still leave large gaps in the understanding how transaction costs, measurement and strategic resources combine to determine the boundaries of the firm. Moreover, the study lacks empirical evidence in order to validate the presented statements. Although the proposals try to address the individual limitations of each theory listed in the literature, and this complementary study indicates an orientation capable of generating positive results, its contributions should be tested and the gaps need to be identified and reduced.

\section{REFERENCES}

ARGYRES, N.; ZENGER, T. Capabilities, Transaction Costs, and Firm Boundaries: A Dynamic Perspective and Integration. Social Science Research Network (SSRN). Available at SSRN: <http://papers.ssrn.com/sol3/papers.cfm?abstract_ id=1081857http://ssrn.com/abstract=1081857>. Acesso em: jun/2008.

. Capabilities, Transaction Costs, and Firm Boundaries. Organization Science, v. 23, n. 6, p. 1643-1657, 2012.

BARNEY, J. Firm resources and sustained competitive advantage. Journal of management, v. 17, n. 1, p. 99-120, 1991.

. Gaining and sustaining competitive advantage (3rd ed.). Upper Saddle River, NJ: Prentice-Hall, 2007.

BARZEL, Y. Organizational Forms and Measurement Costs. Journal of Institutional and Theoretical Economics, v. 161, p. 357-373, 2005.

. Standards and the form of agreement. In: INTERNATIONAL SOCIETY FOR NEW INSTITUTIONAL ECONOMICS, 3, 2003. Anais... ISNIE, Budapeste, Hungria, 2003.

COASE, R. The Nature of the Firm. Economica, v. 4, n. 16, p. 386-405, 1937.

COMBS, J. G.; KETCHEN, D. J. Explaining Interfirm Cooperation and Performance: Toward a Reconciliation of Prediction from the Resource-Based-View and Organizational Economics. Strategic Management Journal, Chichester, v. 20, n. 9, p. 867-888, 1999. 
CROOK, T. R.; COMBS, J. G.; KETCHEN JR, D. J.; AGUINIS, H. Organizing around Transaction Costs: What have we learned and where do we go from here? Academy of Management Perspectives, v. 27, n. 1, p. 63-79, 2013.

FOSS, N. J. The resource-based view: aligning strategy and competitive equilibrium. Strategy, economic organization, and the knowledge economy: the coordination of firms and resources. Oxford: Oxford University Press, 2005.

FOSS, K.; FOSS, N. J. The Next Step in the Evolution of the VBR: Integration with Transaction Cost Economics. Management Revue, v. 15, n. 1, p. 107-121, 2004.

JACOBIDES, M. G.; WINTER, S. G. Co-Evolution of Capabilities and Transaction Costs: Explaining the Institutional Structure of Production. Strategic Management Journal, v. 26, n. 1, p. 395-413, 2005.

KLEIN, B.; CRAWFORD, R. G.; ALCHIAN, A. A. Vertical Integration, Appropriable Rents, and the Competitive Contracting Process. Journal of Law and Economics, v. 21, n. 2, p. 297-326, 1978.

LANGLOIS, R. N. Transaction-Cost Economics in Real Time. Oxford Journal - Industrial and Corporate Change, v. 1, n. 1, p. 99-127, 1992.

LANGLOIS, R. N.; FOSS, N. J. Capabilities and Governance: the Rebirth of Production in the Theory of Economic Organization. Danish Research Unit for Industrial Dynamics. 1997.

LEIBLEIN, M. J. The Choice of Organizational Governance Form and Performance: Predictions from Transaction Cost, Resource-based, and Real Options Theories. Journal of Management, v. 29, n. 6, p. 937-961, 2003.

MAHONEY, J. A resource-based theory of sustainable rents. Journal of Management, v. 27, p. 651-660, 2001.

MELO, A. A. Relações cliente-fornecedor na indústria automotiva. Tese. 2006. 234f. (Doutorado em Administração) - Universidade Federal do Rio Grande do Sul, Escola de Administração, Programa de Pós-Graduação em Administração. Porto Alegre, RS: 2006. 
MONTGOMERY, C. A.; PORTER, M. E. Estratégia: a busca da vantagem competitiva. Rio de Janeiro: Campus, 1998.

NICKERSON, J. A. Toward a Positioning Economizing Theory of Strategy. Mimeo. John M. Olin School of Business. Whashington University in Saint Louis, 2003.

NICKERSON, J. A.; ZENGER, T. R. A Knowledge-Based Theory of the Firm-The Problem-Solving Perspective. Organization Science, v. 15, n. 6, p. 617-632, 2004.

PENROSE, E. T. The theory of the growth of the firm. New York: John Wiley, 1959.

PETERAF, M. A. The cornerstones of competitive advantage: a resource based view. Strategic Management Journal, v. 14, p. 179-191, 1993.

POPPO, L.; ZENGER, T. Testing alternative theories of the firm: transaction cost, knowledge-based, and measurement explanations for make-or-buy decisions in information services. Strategic Management Journal, v. 19, p. 853877, 1998.

SAES, M. S. M. Estratégias de diferenciação e apropriação da quase-renda na agricultura: a produção de pequena escala. São Paulo: Annablume, Fapesp, 2009.

TEECE, D.; PISANO, G.; SHUEN, A. Dynamic capabilities and strategic management. Strategic Management Journal, v. 18, n. 7, p. 509-533, 1997.

WERNEFELT, B. A resource-based view of the firm. Strategic Management Journal, p. 171-180, 1984.

WILLIAMSON, O. E. Comparative economic organization: the analyses of discrete structural alternatives. Administrative Science Quarterly, v. 36, n. 2, p. 269-296, jun., 1991.

Markets and hierarchies: analysis and antitrust implications. New York: Free Press, 1975. 
. Strategy Research: Governance and Competence Perspective. Strategic Management Journal, v. 20, n. 12, p. 1087-1108, dec., 1999.

The economic institutions of capitalism: firms, markets, relational contracting. New York: Free Press, 1985.

. The mechanisms of governance. New York: Oxford University Press, 1996.

ZYLBERSZTAJN, D. Estruturas de governança e coordenação do Agribusiness: uma aplicação da Nova Economia das Instituições. Tese. 1995. 241f. (Livre docência em Administração da Faculdade de Economia, Administração e Contabilidade) - Universidade de São Paulo, São Paulo, SP: 1995.

Papel dos contraltos na coordenação agro-industrial: um olhar além dos mercados. In: SOUZA, J. P.; PRADO, I. N. (Org.). Cadeias produtivas: estudos sobre competitividade e coordenação. 2. Ed. Maringá: EDUEM, 2009.

- Measurement costs and governance: bridging perspectives of transaction cost economics. In: International Society for the New Institutional Economics - ISNIE, Barcelona-Espanha, 2005. 